\title{
THE IMPLEMENTATION OF CUSTOMER RELATIONSHIP MANAGEMENT (CRM) SUPPORTED BY SMS GATEWAY TECHNOLOGY
}

\author{
Komang Redy Winatha \\ Informatics Engineering, STMIK STIKOM Indonesia, Denpasar, Bali \\ E-mail: redywin@stiki-indonesia.ac.id
}

\begin{abstract}
ABSTRAK
Menyikapi persaingan industri restoran yang semakin tinggi, restoran Mailaku Roemah Nongkrong kurang fleksibel dalam menyikapi perubahan lingkungan dengan masih memakai teknologi manual disaat perkembangan teknologi yang semakin maju dan masih mengandalkan sumber daya internal untuk pengembangan bisnis. Salah satu langkah yang dapat ditempuh untuk mengatasi permasalahan ini dengan memanfaatkan teknologi dan konsep customer relationship management (CRM). CRM merupakan strategi pemasaran untuk menciptakan dan mempertahankan hubungan pelanggan dan mengurangi kemungkinan pelanggan pindah ke pesaing lain. Penelitian ini menyajikan pengembangan dan penerapan CRM dalam sebuah sistem berbasis web yang didukung dengan teknologi sms gateway. Metodologi penelitian yang akan digunakan dalam penelitian ini terdiri dari langkah-langkah yaitu studi kepustakaan, observasi, wawancara, dan pengembangan sistem yang terbagi atas analisis, design, coding, dan pengujian. Hasilnya adalah sistem berbasis web yang mampu mengelola data pelanggan, promosi produk, dan pengelolaan layanan pelanggan untuk menciptakan hubungan yang baik dengan pelanggan. Sistem ini dapat menjadi alternatif bagi restoran dan pelanggan dalam menjalin komunikasi bisnis yang praktis.
\end{abstract}

Kata kunci: Pelanggan, Customer Relationship Management, SMS Gateway, Web

\begin{abstract}
Responding to the higher restaurant industry competition, the Mailaku Roemah Nongkrong restaurant was not too flexible in facing an environmental change. It was still using manual technology while there was an advancing technological developments. It was still applying the internal resources for business development. One way to overcome this problem is by utilizing technology and the concept of customer relationship management (CRM). CRM is a marketing strategy to create and maintain customer relationships and reduce the possibility of customers moving to other competitors. This study presented the development and implementation of CRM in a web-based system that was supported by SMS gateway technology. The research methodology that will be used in this study consists of some steps, such as library study, observation, interviews, and system development which was divided into analysis, design, coding, and testing. The result was a web-based system was able to manage customer data, product promotion, and customer service management to create good relationships with customers. This system can be as an alternative for restaurants and customers in establishing practical business communication.
\end{abstract}

Keywords : Customers, Customer Relationship Management, SMS Gateway, Web

\section{INTRODUCTION}

Business is one of enterprise opportunities that inviting many people interest this time. By developing a business field, a person is able to develop their abilities and creativity in creating an innovation that is really needed and in demand by the community so that they can create jobs and increase income. But practicall, developing a business is not easy, it requires a willingness, ability and hard work so that the business can attract the attention and interest of customers. 
The high of business opportunities in economic developments nowadays presents many new business actors in various business fields, one of them is the restaurant business. From year to year, the restaurant business in Indonesia has increasing. This high growth is as high as the level of competition among restaurants. Restaurant competition is not only about how to get as many customers / customers as possible so that profits increase, or how to innovate the products produced, but now competition is also in the form of retaining customers and giving customers satisfaction so that customers feel served as kings. Understanding customer needs and expectations is very important for a customer-oriented company [1]

In responding the competition, Mailaku Roemah Nongkrong that is located in Singaraja City, Buleleng Regency, Bali has its own business strategy that is in accordance with its vision and mission. However, in an effort to maintain his identity as a restaurant, Mailaku Roemah Nongkrong is not too flexible in facing environmental changes. This restaurant still uses manual technology while advancing technological developments and still relies on internal resources for business development while other restaurants are increasingly expansive by adopting the franchise business format. The transaction process and administrative documentation are still manual that make the service to consumers less effective.

Because of that, a proper way is needed so that the Mailaku Roemah Nongkrong restaurant can understand its customers better and give them a better service. One way to establish the relationships with these customers is to build Customer Relationship Management (CRM). CRM is an infrastructure that enables the depiction and improvement of customer value, and uses the right method to motivate regular customers to come and buy again [2]. CRM can also be defined as a marketing strategy that is currently very much carried out by companies that want their customers to buy products or use their services, in the general sense that is a process of several stages consisting of identification, acquisition, retention and consumer development that gives a large contribution to the company by focusing its strategy by maintaining effective and efficient relationships with consumers so that the relationship becomes a profitable lifetime [3]

The purpose of this research is to build a CRM application with web-based Operational CRM which supported by SMS gateway technology. SMS gateway is communication using SMS which contains information in the form of the sender's cell phone number, receiver, time and message [4]. This technology will easily facilitate the communication between the company and its customers so that closeness is established. This closeness can be like comments, customer rewards, and information media that will improve the service quality and consumers' satisfaction of services received.

\section{RESEARCH METHOD}

Problems that arise are caused by the old system that is still manual and not well organized very diverse, including the length of the transaction process, invalid purchase or sale transaction reports, lack of proximity of the restaurant with its customers which causes a reduction in the number of customers and so on. The results of data collection and process analysis of existing systems, it can be concluded that the problem can be resolved by the existence of a computerized system through the Customer Relationship Management (CRM) approach which is supported by SMS Gateway technology that is well organized so that it can provide valid information and establish closer relationships with customers.

The research methodology that will be used in this research consists of some steps. The first step is literature study, carried out by searching for supporting literature of research that is able to provide adequate information in completing this study and help reinforce existing theories. The next step is the observation method, observation is conducted directly to the research's objects regarding the administrative process that is still done manually in Mailaku Roemah Nongkrong. The next one is the interview which conducts a question and answer activity by face to face with the respondent to obtain information verbally for obtaining data that can explain or answer a research problem. The last step is the development of a system that is divided into analysis, design, coding, and testing. Analysis is the decomposition of a complete information system into its component parts with the intention of identifying and evaluating problems, opportunities, obstacles that occured and expected needs so that improvements can be proposed. Analysis of software requirements is done to explore the software requirements that will be developed. The results of the software requirements analysis document are in the form of a Software Requirements Specification document (SKPL). System design can be defined as drawing, planning and making sketches or arrangements of several separate elements into a single unit that is intact and functioning. This stage consists of several activities including: designing data flow diagrams, databases, entity relationship diagrams, sitemap, and interfaces. While the coding 
applied in the form of software implementation is done by making a program or application information system in the implementation of CRM in Mailaku Roemah Nongkrong. The system is built with the PHP programming language, MySQL database, and gammu as an SMS gateway module. Before the software is submitted to the owner or agency that needs it, the software must be evaluated to ensure it has fulfilled functional and non-functional needs. This CRM application was tested in 3 different classifications, including: (a) functional testing, focusing on functional requirements of software that have been previously set. Testing CRM applications is supported by SMS Gateway technology in Mailaku Roemah Nongkrong. This is done by using test data in the form of data input that will be processed by the admin, marketing, and cashier; (b) non-functional testing, this test is carried out by using the browser to find out the functions of the menus and the web display running well or vice versa; and (c) testing user satisfaction, this test was tested by giving questionnaires to users consisting of 10 restaurant staffs and 10 customers. This test is conducted to find out whether the steps carried out have gone well and this test is very helpful in improving the software that was built.

This research focuses on the application of CRM on the operational side, where operational CRM serves to provide support for business processes at the front office, such as for sales, marketing and service staff [5]. Operational CRM that is built is a system of information on sales and marketing transactions in Mailaku Roemah Nongkrong, including buying and selling transactions, consumer purchasing history, offering to consumers, and automation of marketing and sales. The system built is expected to be able to improve the quality of transaction services to consumers.

\section{RESULT AND DISCUSSION}

The results of this research were the software that could be used by Mailaku Roemah Nongkrong to provide maximum service to its customers. In CRM development, the initial stage was to determine the requirements planning for the operational CRM application that was built. The CRM application focused on transactions and marketing strategies. From the results of the planning requirements obtained that the operational CRM software must be able to: 1 . display the purchase history of consumers Mailaku Roemah Nongkrong, 2. provide birthday greetings automatically for consumers who are registered as members via SMS, 3. inform the total transactions that have been made via SMS, 4. inform the promos to consumers via broadcast messages, 5 . Display the products that are most often ordered by consumers, and 6 . show the number of transactions that have been done along with total income automatically.

The next stage was design. This stage produced a visual display of the user interface of the system being built. System users were divided into 4 groups, such as admin, marketing, cashier, and customer. The following were some of the Operational CRM application views that were built. The initial view that will be seen by the user when entering into this system is shown in Figure 1.

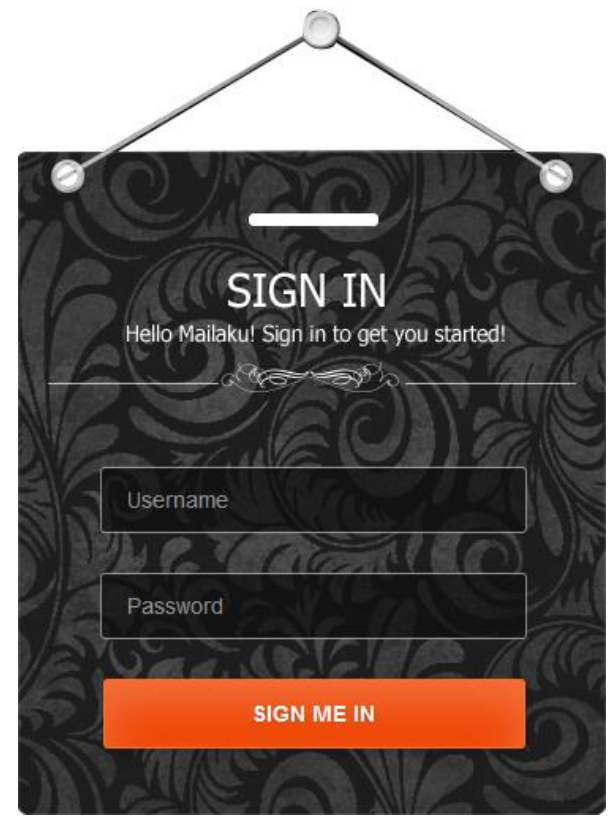

Figure 1. Sign in page

This page contains a dialog box that asks the user to enter a username and password. If the username and password have been registered, the user will enter the main menu. If the username and 
password have not been registered, then the user cannot enter the main menu and in this case, the user is expected to register first with the admin.

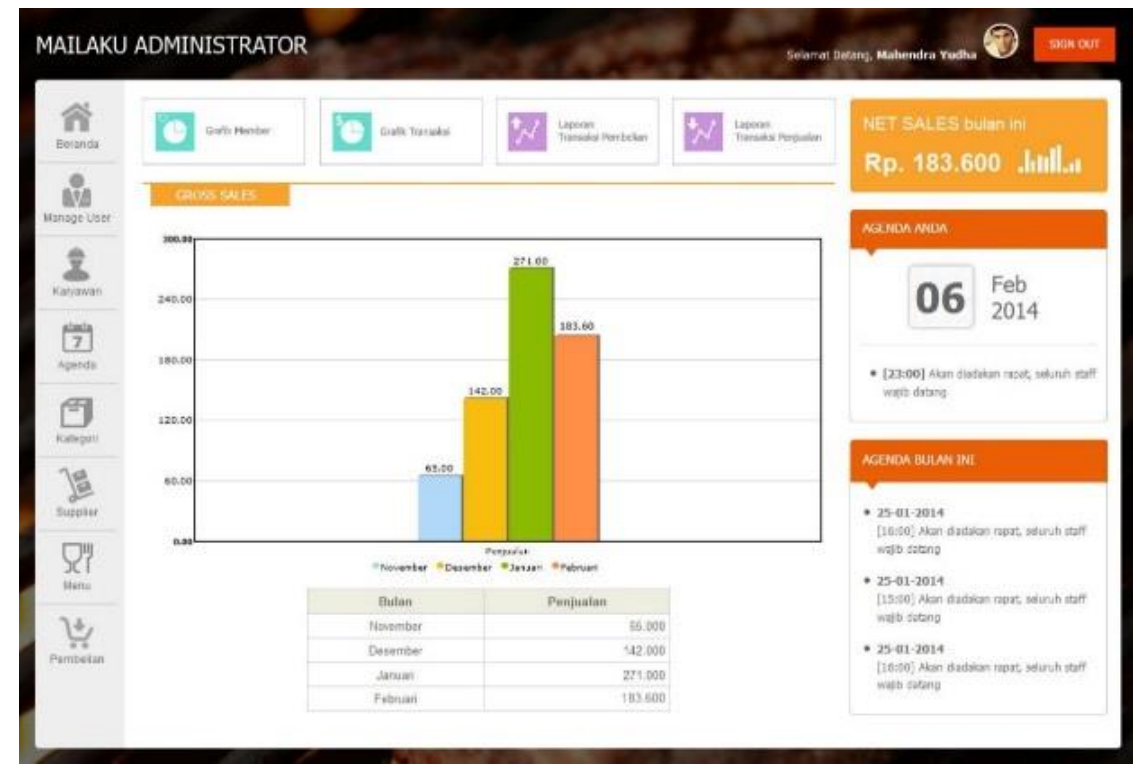

Figure 2. Page views of users who accessing as administrator

Figure 2 is the start page view of the user who can access as an administrator. In this poin, there were several functions that can be performed by the user including user management, employee management, user agenda management, agenda, menu categories, menus, suppliers, purchase transactions, and reports.

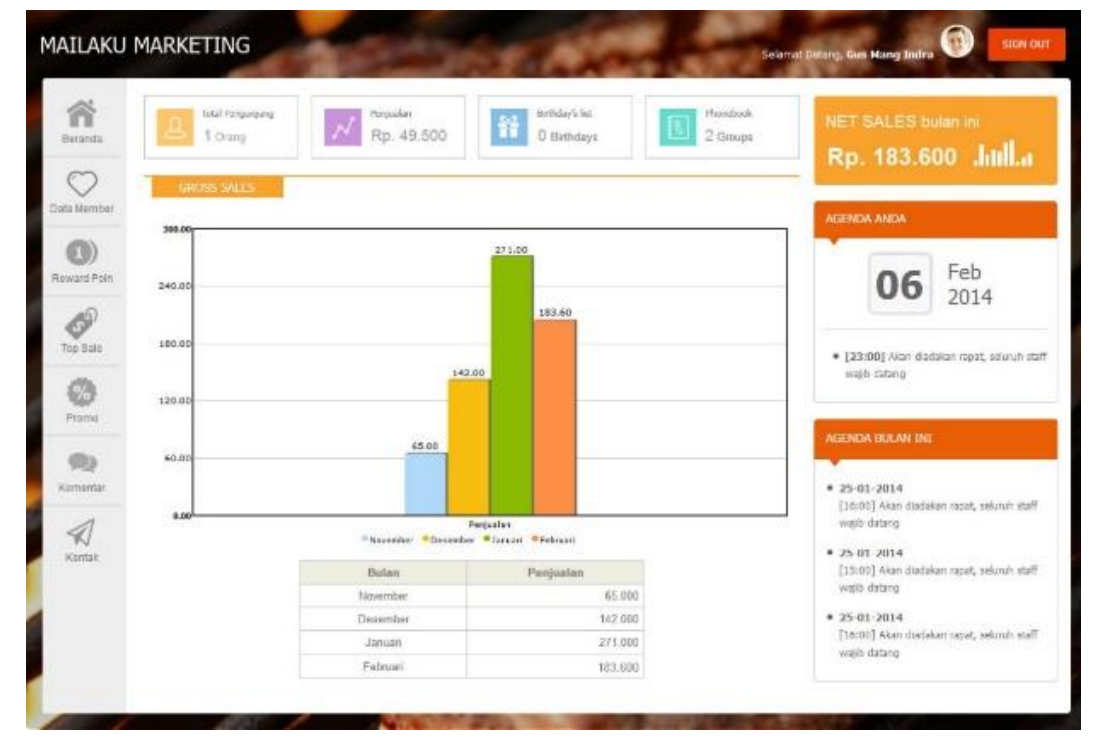

Figure 3. Page views of users who accessing as marketing

Figure 3 is the start page for users who accessing as marketing. The initial appearance consisted of four parts, namely: main navigation in the form of processing buttons, profiles in the form of user information, agenda in the form of information on agenda that must be done by staff, and main content containing sales notifications and member birthdays and sales charts. In this access right, there are several functions that can be performed by the user, including monitoring member data, viewing members who are on birthday, SMS applications, gift data, promo management, viewing customer comments, and replying to customer contacts. 


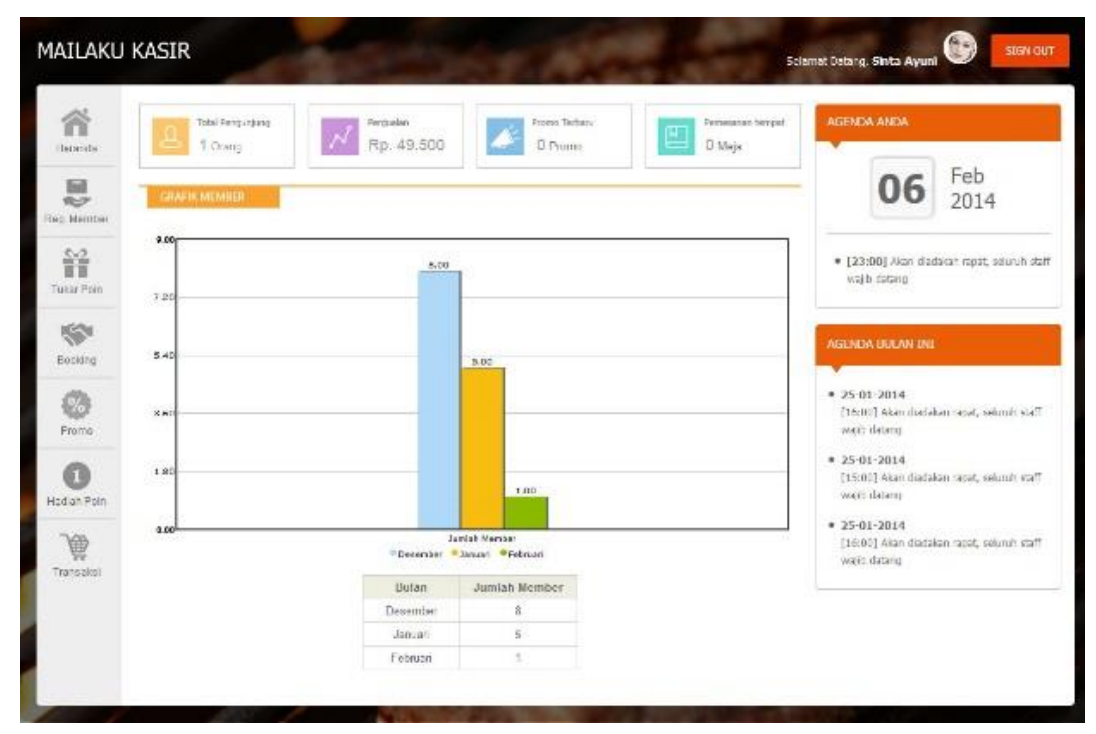

Figure 4. Page views of users who accessing as cashier

Figure 4 is the start page of the user who accessing as a cashier. The initial appearance consisted of four parts, namely: main navigation in the form of processing buttons, profiles in the form of user information, agenda in the form of information on agenda that must be carried out by staff, and main content that contains sales notifications and graphs of monthly number of members. In this access right, there are several functions that can be performed by the user including new member registration, point exchange, place reservations, sales transactions, and data that the cashier needs to know such as promo data and gift data to be delivered to customers.

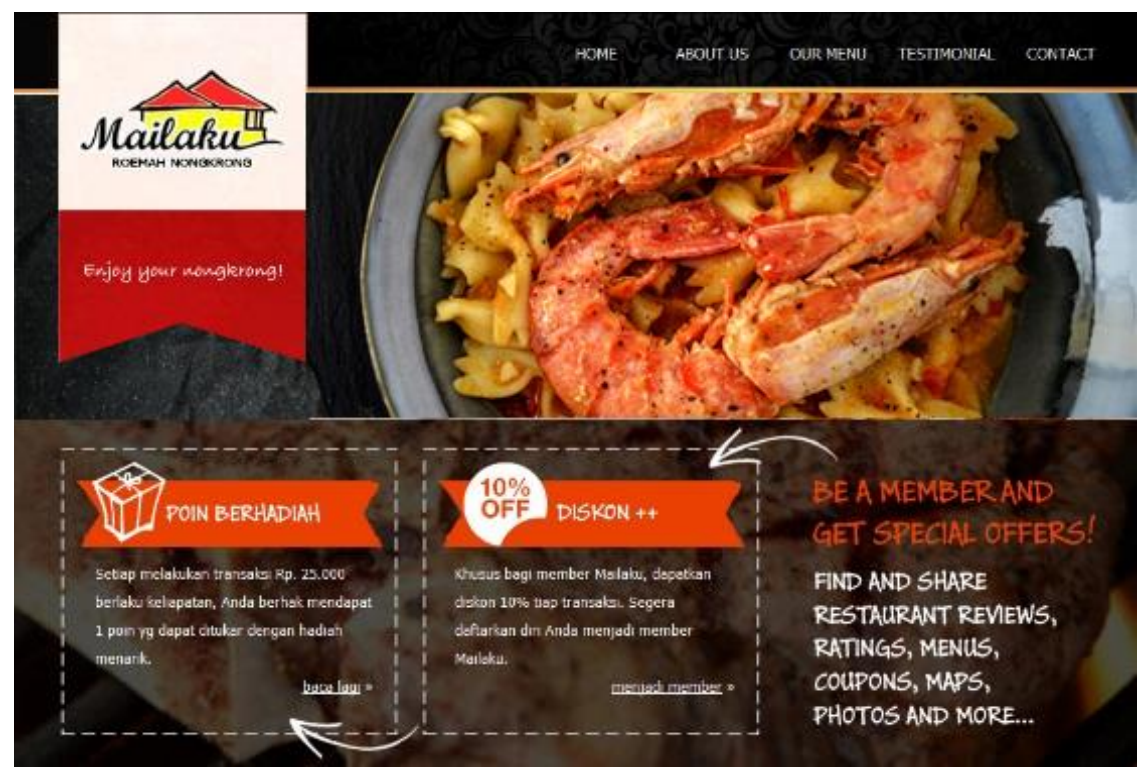

Figure 5. Display of visitor pages

Figure 5 is the appearance of the visitors' home page. In this page, there are several functions that can be performed by users, including finfing out the profiles, menus, comments, asking questions, and knowing the promos that are being held. The restaurant information media, which is packaged in the form of a website, becomes an attraction for online consumers, easily accessible to consumers to find information, has a display that meets human and computer interaction rules, contains multimedia elements, facilitates restaurants to inform products and the latest promos which is very good because it can be accessed for 24 hours and is not limited to time and place [6]. Sales promotion had a positive and significant effect on purchasing decisions on consumers [7]. 
SMS gateway is a facility provided in a special CRM operational system for registered customers (members). Through the cashier, customer data that will become a member is inputted in the system. The data of custumers was such as the name, place and date of birth, address and telephone number. This data will be processed as supporting data to determine customer habits, and increase customer loyalty through promos.

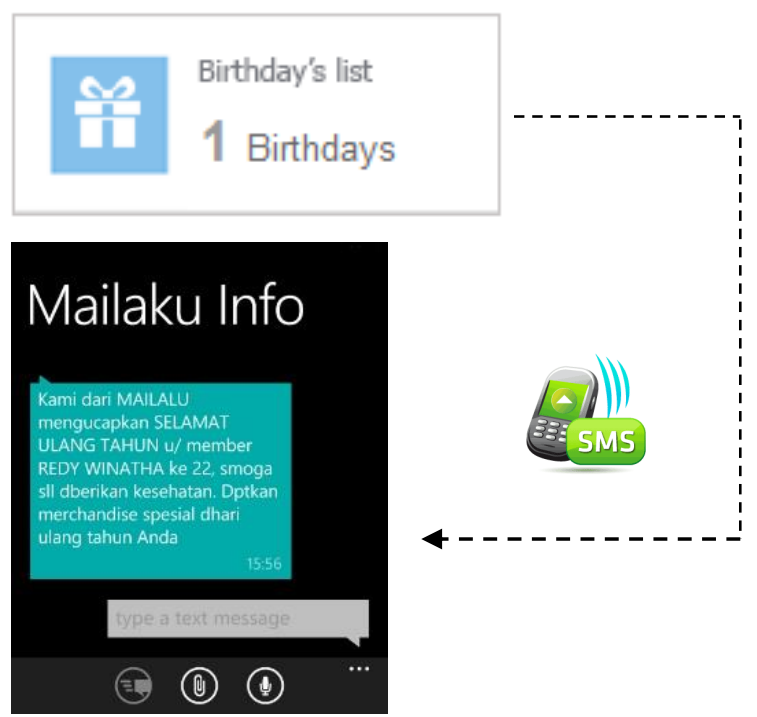

Figure 6. SMS Birthday

Figure 6 shows if there is a member's birthday, the system will automatically send a birthday greeting SMS. Saying birthday to customers, is a form of strategy to build relationships with customers[8]. With this strategy, customers will feel flattered for the attention given so they feel satisfied with service and build loyalty.
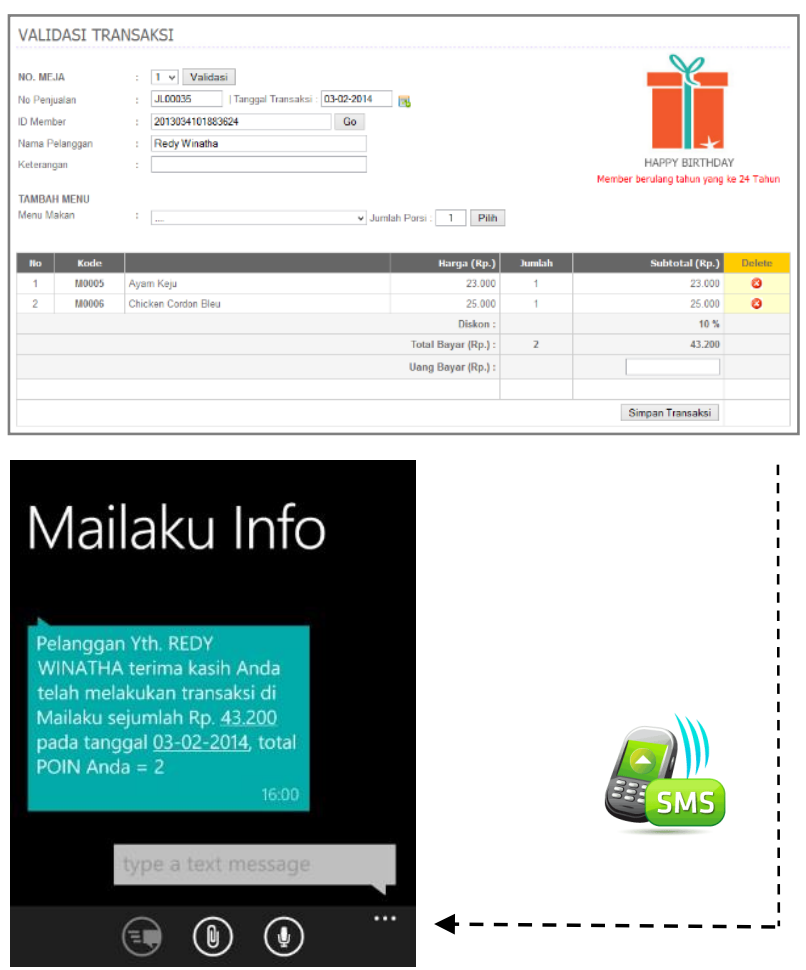

Figure 7. SMS to customers after a transaction 
After the member makes a transaction, the system will automatically send an SMS thank you for the transaction along with the total points collected. This facility is a strategy to provide value for each transaction of the member and efford to maintain the old customers by giving prizes according to the points collected. The process results can be seen in Figure 7.
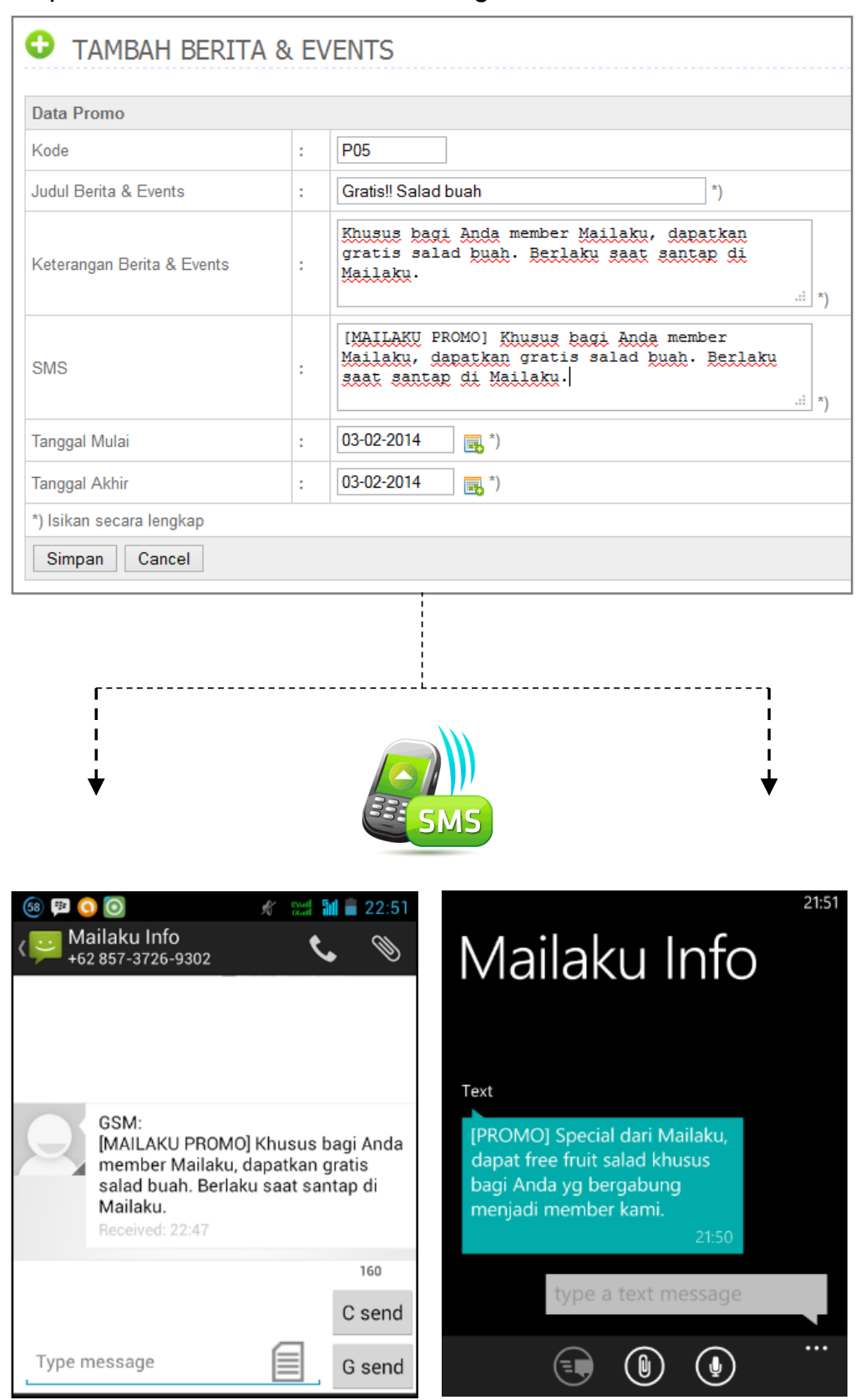

Figure 8. SMS of broadcast promo

Figure 8 shows a broadcast message that will be sent to all members after the user as marketing input a promo data. This is certainly very beneficial for customers, because based on the research, the higher the benefits that can be obtained by consumers will affect the high and low customer satisfaction [9]. SMS broadcasts will also help the process of delivering the latest information faster to customers [10]. 


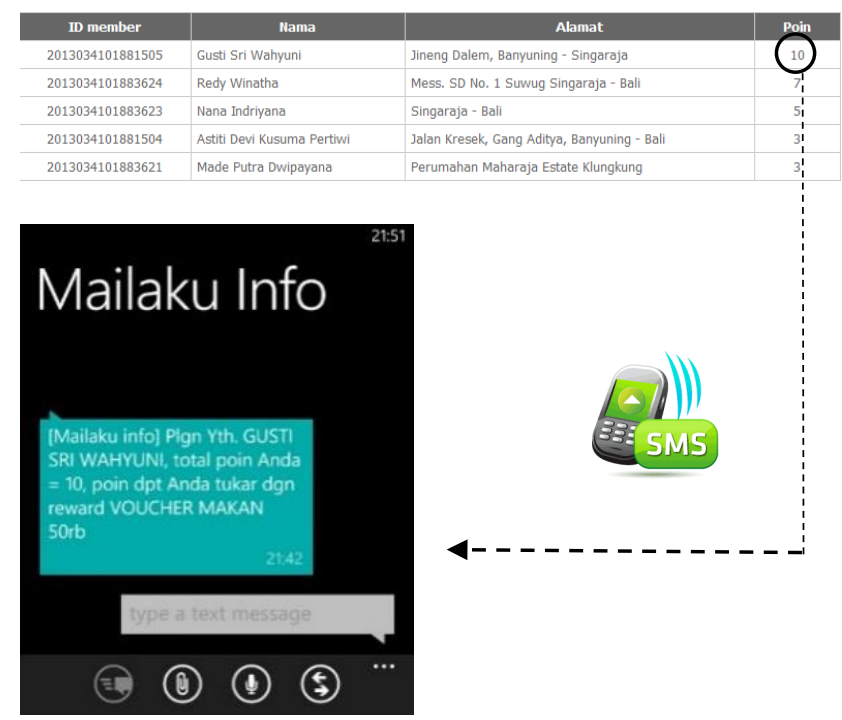

Figure 9. SMS of point redemption

In Figure 9, it explains if the member points are enough to exchange prizes, the system will send member points SMS that can be exchanged for prizes according to the number of points. This is a company strategy to maintain customers who have high loyalty.

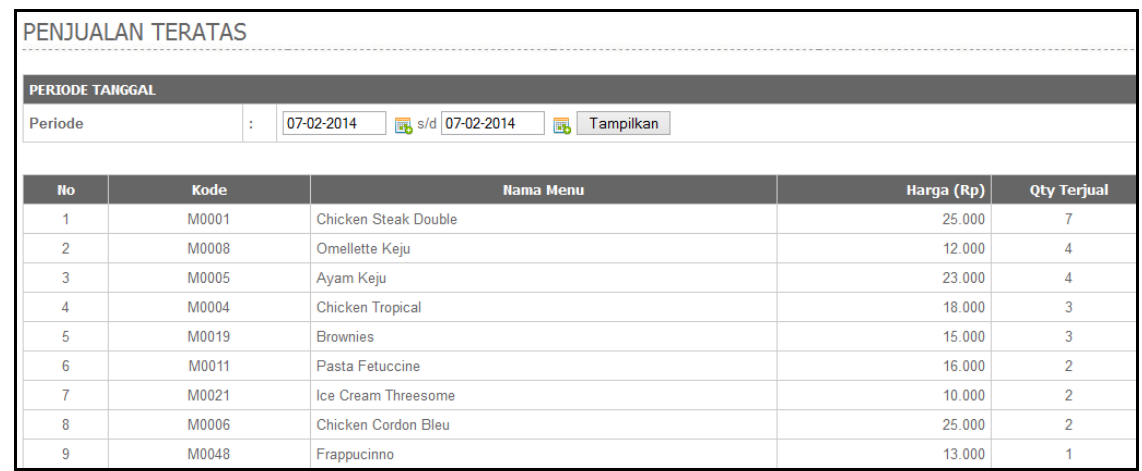

Figure 10. Top sales

Figure 10 shows the top sales data for all menus sold by restaurant customers. This data can be used by CRM Analysis to see the market trends and trends of each customer based on the products purchased and as a consideration for restaurants to hold product promos or innovations that will be made next.

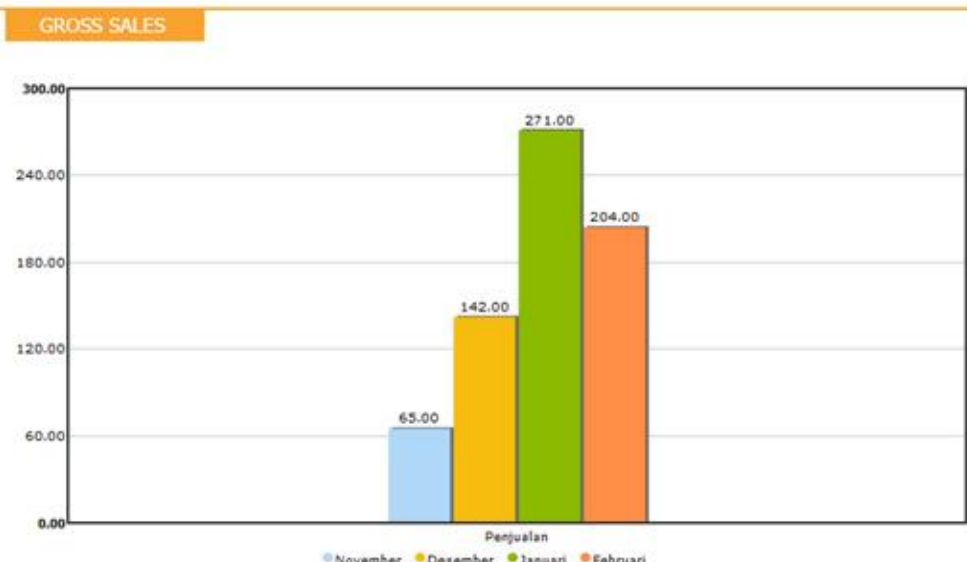

Figure 11. Sales graph 
Figure 11 shows a graph of sales every month obtained from the results of customer transactions. The last stage of Operational CRM application development was implementation, and also testing and evaluation before finally being used. Tests were based on functional, non functional systems and user satisfaction. Functional testing used 29 module parameters (23 admin modules and 6 customer modules). Non functional testing was based on system functions tested with 4 different browser (browser). While testing based on user satisfaction used the parameters of 10 professional questions distributed to 20 users, including 10 users as restaurant staff and 10 users as randomly selected customers.

The result of The functional system test from 29 modules were all modules can run properly. On the other hand, the results of non-functional testing showed that CRM applications can run well using the latest version of Mozilla Firefox, Opera, and Google Chrome web browsers. The results of the questionnaire were conducted on 10 staff respondents and restaurant customers with 10 criteria provided showed that $83 \%$ stated that the CRM application was very good, $14 \%$ stated good, and $3 \%$ stated enough based on visual design, navigation, and CRM features. The results of the questionnaire were conducted to 10 customers restaurant with 10 criteria provided, it was found that $81 \%$ stated that the CRM application was very good, $15 \%$ said it was good, and $4 \%$ stated it was based on visual design, navigation, and CRM features.

\section{CONCLUSION}

System development by implementing customer relationship management (CRM) supported by SMS gateway technology was successfully built. Based on the results of a functional testing system consisting of 29 modules, everything can work well. While based on non-functional testing, the software can run well using the latest version of Mozilla Firefox, Opera, and Google Chrome web browsers. The results of the questionnaire were conducted on 10 staff respondents and restaurant customers with 10 criteria provided showed that the software included into very good category in terms of visual design, navigation, and CRM features. As for suggestions for further research related to this topic including: (a) the application is still limited to local web servers. For further development, web service features can be added to the server, so that the application can be accessed by users through internet access from everywhere; (b) it can added facility to read the member card barcode on the sales transaction, so that the cashier does not need to enter the member code manually; (c) on the customer's page, each food menu is given an explanation so that the customer knows the description of the menu in question, and (d) the ordering process of the menu can be made in a mobile version to make it easy for restaurant customers.

\section{REFERENCES}

[1] S. Nuryudayatun, "Membangun Kepuasan Pelanggan dengan Melakukan Customer Understanding," JBMA, vol. I, no. 2, pp. 17-24, 2013.

[2] J. Dyché, The CRM Handbook: A Business Guide to Customer Relationship Management. Addison-Wesley Professional, 2001.

[3] E. Fauzi, Ahmad; Harli, "Peningkatan Kualitas Pelayanan Melalui CRM dengan Metode RAD," J. RESTI (Rekayasa Sist. dan Teknol. Informasi), vol. 1, no. 1, pp. 76-81, 2017.

[4] M. Afrina, A. Ibrahim, J. Sistem, I. Fasilkom, and U. Sriwijaya, "Pengembangan Sistem Informasi SMS Gateway Dalam Meningkatkan Layanan Komunikasi Sekitar Akademika Fakultas IImu Komputer Unsri," J. Sist. Inf., vol. 7, no. 2, pp. 852-864, 2015.

[5] A. N. Khusna, "Aplikasi Operational Customer Relationship Management Pemasaran Keripik Jamur Bu Sayom," Semin. Nas. Apl. Teknol. Inf., pp. 30-33, 2016.

[6] B. Yulianto, L. C. Dewi, and O. Wijaya, "Peran Website Restoran terhadap Daya Tarik Konsumen Online," Comtech, vol. 5, no. 2, pp. 1096-1109, 2014.

[7] A. A. G. A. A. Windusara, Dewa Bagus Nugraha; Kusuma, "Pengaruh Bauran Promosi terhadap Keputusan Pembelian Oppo Smartphone," E-Jurnal Manaj. Unud, vol. 4, no. 5, pp. 1271-1282, 2015.

[8] F. Harnoto, "Strategi Kepuasan Pelanggan dalam Mempertahankan dan Meningkatkan Loyalitas Pelanggan," J. Ekon. Manajamen dan Akutansi, vol. 21, no. 36, 2014.

[9] A. Chandra, H. Semuel, R. K. M. R. Brahmana, J. M. Pemasaran, U. K. Petra, and J. Siwalankerto, "Pengaruh aktivitas customer relationship marketing terhadap kepuasan pelanggan melalui manfaat penerapan relationship marketing di excelso galaxy mall surabaya," J. Manaj. 
Pemasar., vol. 1, no. 1, pp. 1-8, 2013.

[10] F. D. Silalahi and I. Koerniawan, "Layanan Informasi Berbasis Store and Forward Analisis dan Implementasi SMS Gateway sebagai Auto-Respon Layanan Informasi Berbasis Store and Forward," J. Teknol. Inf. dan Komun., vol. 8, no. 2, pp. 30-38, 2017. 